American Journal of Biochemistry and Biotechnology 4 (4): 325-328, 2008

ISSN 1553-3468

(C) 2008 Science Publications

\title{
Plantlet Production through Development of Competent Multiple Meristem Cultures from Male Inflorescence of Banana, Musa acuminta cv. 'Pisang Mas' (AA)
}

\author{
S. Wirakarnain, A.B.M.S. Hossain and S. Chandran \\ Institute of Biological Sciences, Faculty of Science, \\ University of Malaya, 50603, Kuala Lumpur, Malaysia
}

\begin{abstract}
A protocol was developed for the establishment of competent multiple meristem cultures of banana, Musa acuminta cv. 'Pisang Mas' (AA) derived from male inflorescence. The white floral meristem appeared after 21 days in medium supplemented with $10 \mu \mathrm{M}$ of N6-benzylaminopurine (BA) and $1 \mu \mathrm{M}$ Indole -3-Acetic Acid (IAA). White floral meristem were optimized in medium supplemented with $100 \mu \mathrm{M}$ (BA) and $1 \mu \mathrm{M}$ (IAA) until a high amount of compact floral meristem were obtained. However these compact floral meristems were induced a low number of multiple shoots. Therefore, the compact floral meristem were induced to maximum number of green multiple meristem cultures after 14 days in medium supplemented with $20 \mu \mathrm{M}$ NAA (naphthaleneacetic acid), $1 \mu \mathrm{M}$ (IAA) and $100 \mu \mathrm{M}$ of BA .Further cultured of individual shoot clusters from green multiple meristems resulted in $12.3 \pm 0.26$ shoots multiplication when cultured onto MS medium supplemented with $100 \mu \mathrm{M}$ of N6-benzylaminopurine (BA) and $1 \mu \mathrm{M}$ indole -3-acetic acid (IAA). The regenerated shoots were rooted after being transferred onto MS medium supplemented with $1 \%(\mathrm{w} / \mathrm{v})$ of activated charcoal for 14 days. This study has demonstrated that green competent multiple meristem culture derived from male inflorescence can produce plantlet and could be an alternative material for mass micropropagation of bananas.
\end{abstract}

Key words: Banana, competent meristem, male flowers, micropropagation

\section{INTRODUCTION}

Bananas (Musa spp.) are grown in all tropical regions and play a key role in the economies of many developing nations. Total world export volume in 2004 was 22.8 million tones. ${ }^{[1]}$. Since most banana produce seedless fruits, they are vegetatively multiplied in vivo as well in vitro. Conventional propagation of Musa spp. depends on planting young suckers, sword suckers and corms suffer slow multiplication rate. For large scale plantings sufficient quantities are needed. Therefore, in vitro techniques have become most popular technique for producing high number of plantings material for banana.

Mas banana (an AA diploid) is the most favoured banana in Malaysia and ia in high demand for commercial planting. Consequently, in vitro micropropagation techniques have become very useful for mass propagation of Mas bananas. The starting materials used in vitro propagation of Mas bananas were meristem derived from corm tissue ${ }^{[2]}$ and shoot tips $^{[3]}$. On the other hand, somatic embryogenesis techniques has also been developed as an alternative technique for mass propagation. The starting materials used include young zygotic embryos ${ }^{[4,5]}$ male bud inflorescence ${ }^{[6-8]}$ and female flowers ${ }^{[9]}$. Although, the somatic embryogenesis techniques can produce mass number of plantlets compared to in vitro micropropagation techniques, there are possibilities of high percentage of "off types" being produced from this methodology ${ }^{[10]}$. The current trend have exploits the meristem inflorescences as materials for in vitro micro propagation techniques ${ }^{[11-13]}$ because these materials reduce the contamination rate compared to soil grown suckers. However the number of shoots produced is still a limiting factor. The present study was performed to produce competent multiple meristem from male inflorescence of Mas bananas by using in vitro techniques. For this purpose, competent multiple meristem cultures were induced and selected by manipulating the plant growth regulators (combination

Co-responding Author: S. Wirakarnain, Institute of Biological Sciences, Faculty of Science, University of Malaya, 50603, Kuala Lumpur, Malaysia Tel: +603-79674003 Fax: +603-79674178 
of cytokinin and auxin) and to produce high number of shoot from these materials.

\section{MATERIALS AND METHODS}

Plant materials: Inflorescence male bud of Musa acuminata cv. 'Pisang Mas' (AA) were obtained from a farm in Kota Tinggi, Johore Bahru located $415 \mathrm{~km}$ from Kuala Lumpur. Male inflorescences were collected when all the female flowers in a bunch were completely exposed and were cultured within 3 days of collection.

Preparation of explants: The male bud of Musa acuminata cv. Pisang Mas' (AA) were dissected and shortened to $6-8 \mathrm{~cm}$ in length. The explants were then disinfested with $70 \%$ volume of alcohol for $10 \mathrm{~min}$ and rinsed with sterile distilled water three times. Then 50 explants were cut longitudinally to halves and were placed onto a semi solid medium (Fig. 2A).

Cultural conditions, screening procedure and regeneration: The 100 explants derived from 50 inflorescence male buds were sub cultured onto $\mathrm{MS}^{[18]}$ semi solid medium supplemented with $10 \mu \mathrm{M}$ of N6benzylaminopurine (BA), $1 \mu \mathrm{M}$ Indole -3- Acetic Acid (IAA), $2.0 \mathrm{mg} \mathrm{L}^{-1}$ gylcine, $0.4 \mathrm{mg} \mathrm{L}^{-1}$ thiamine $\mathrm{HCl}$, $0.5 \mathrm{mg} \mathrm{L}^{-1}$ nicotinic acid, $0.5 \mathrm{mg} \mathrm{L}^{-1}$ pyridoxine, $10 \mathrm{mg}$ $\mathrm{L}^{-1}$ ascorbic acid and $30 \mathrm{~g} \mathrm{~L}^{-1}$ sucrose (standard banana multiplication medium $)^{[19]}$ The $\mathrm{pH}$ of the medium was adjusted to 5.8 prior to autoclaving and the explants were incubated at $26 \pm 2^{\circ} \mathrm{C}$ and exposed to light from cool white fluorescence tube $(3500$ lux $)$ for a photoperiod of $16 \mathrm{~h}$. Explants were left for 21 days without subculture.

After 21 days, explants were swelled up and turned green in color with the superficial bract curved outwards and exposing the rudimentary flowers. The white rudimentary flowers which appeared as white proliferating floral meristem were selected and optimised on to MS semi solid medium supplemented with $100 \mu \mathrm{M}$ of N6-benzylaminopurine (BAP), $1 \mu \mathrm{M}$ Indole -3-Acetic Acid (IAA), $2.0 \mathrm{mg} \mathrm{L}^{-1}$ gylcine, $0.4 \mathrm{mg} \mathrm{L}^{-1}$ thiamine $\mathrm{HCl}, 0.5 \mathrm{mg} \mathrm{L}^{-1}$ nicotinic acid, $0.5 \mathrm{mg} \mathrm{L}^{-1}$ pyridoxine, $10 \mathrm{mg} \mathrm{L}^{-1}$ ascorbic acid and $30 \mathrm{~g} \mathrm{~L}^{-1}$ sucrose. Subsequently, subculture was done every 14 days.

After 43 days the optimiseds white compact floral meristem were selected and transferred onto a medium which consisted of different concentration of NAA. As soon as the white compact floral meristem induce to Multiple Meristem Cultures (MMC), these explants were selected and transferred onto a medium supplemented with $10 \mu \mathrm{M}$ of N6-benzylaminopurine (BA), $1 \mu \mathrm{M}$ indole -3- acetic acid (IAA), $2.0 \mathrm{mg} \mathrm{L}^{-1}$ gylcine, $0.4 \mathrm{mg} \mathrm{L}^{-1}$ thiamine $\mathrm{HCl}, 0.5 \mathrm{mg} \mathrm{L}^{-1}$ nicotinic acid, $0.5 \mathrm{mg} \mathrm{L}^{-1}$ pyridoxine, $10 \mathrm{mg} \mathrm{L}^{-1}$ ascorbic acid and $30 \mathrm{~g} \mathrm{~L}^{-1}$ sucrose for shoot induction. Finally, the individual shoots of 6-8 cm length were separated and transferred to MS basic medium supplemented with $1 \%$ (w/v) activated charcoal for rooting.

\section{RESULTS}

After being cultured for 10 days in $10 \mu \mathrm{M}$ of (BA), $1 \mu \mathrm{M}$ (IAA) medium the explants started to swell up and turned green in color. The superficial bract curved outwards and exposed the white rudimentary flowers meristem (Fig. 2B). However, when the BA concentration was increased to more than $100 \mu \mathrm{M}$ the explants did not show any responses and instead were covered by a thick black layer (Fig. 1). White rudimentary flower meristems were visible after 21 days in the same medium. At this stage, the white floral meristem were dissected and placed on $100 \mu \mathrm{M}$ of (BA) and $1 \mu \mathrm{M}$ (IAA) medium. On average, $61 \%$ of the white rudimentary floral meristem produced compact white proliferating meristem after 43 days (Fig. 2C). However when the concentration of BA is increased to more than $100 \mu \mathrm{M}$ the white floral meristem turned dark brown in color and eventually became necrotic after 3 days (Fig. 1).

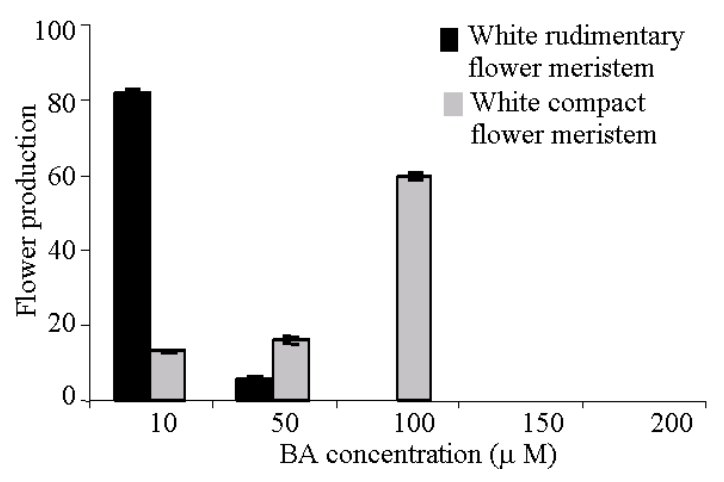

Fig. 1: Production of white rudimentary flower and white compact floral meristem in response to different BA concentration and constant IAA $(1 \mu \mathrm{M})$ 

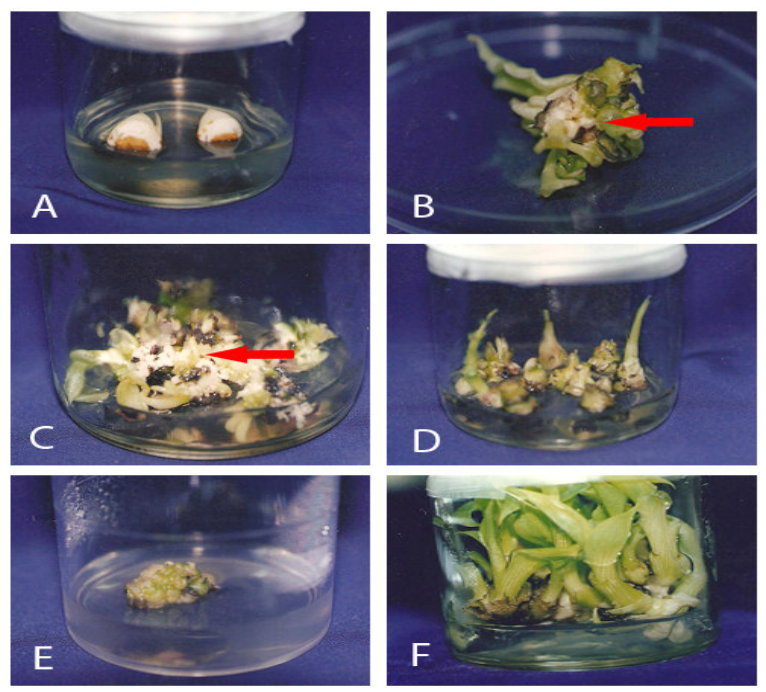

Fig. 2(A-E): Development of shoots from green scalps derived from male inflorescence of Musa acuminta cv. 'Pisang Mas' (AA). (A): Dissection of male bud was shortened to 6-8 $\mathrm{cm}$. (B): The superficial bract curved outward and exposing the white rudimentary meristem. (C): The proliferation of white floral meristems. (D): Formation of shoots derived from white floral meristems. (E): formation of green competent meristem, (F): Development of vigorous shoots derived from green competent meristem

However the white compact floral meristem produced low number of shoots when transferred to a regeneration medium consisting $10 \mu \mathrm{M}$ of (BA) and $1 \mu \mathrm{M}$ (IAA) medium (Fig. 2D). White compact floral meristem exhibited maximum number of $9.6 \pm 0.98$ green multiple meristem cultures per surface, when transferred to medium supplemented with $20 \mu \mathrm{M}$ of NAA (Fig. 2E). These green multiple meristem cultures produced vigorous shoots 8 weeks days after the explants when transferred to a medium consisting 10 $\mu \mathrm{M}$ of (BA) and $1 \mu \mathrm{M}$ (IAA) (Fig. 2F). Further culture of individual shoot clusters resulted in $12.3 \pm 0.26$ shoots multiplication when cultured onto MS medium supplemented with $100 \mu \mathrm{M}$ of N6benzylaminopurine (BA) and $1 \mu \mathrm{M}$ indole -3-acetic acid (IAA) (Table 1). These multiple meristem culture thus considered as competent meristem or active meristem $^{[18]}$..
Table 1: Influence of different combination of $100 \mathrm{BA} \mu \mathrm{M}$ with different NAA concentration. for MMC production and shoot proliferation onto rooting medium

\begin{tabular}{llc}
\hline $\begin{array}{l}\text { Hormone } \\
\text { concentration } \\
\text { NAA }(\mu \mathrm{M})\end{array}$ & MMC & $\begin{array}{l}\text { Average No. } \\
\text { of shoot/explant } \\
\text { of MMC }\end{array}$ \\
\hline 1 & $5.3 \pm 0.94$ & $2.80 \pm 0.98$ \\
5 & $7.3 \pm 0.72$ & $6.60 \pm 0.27$ \\
20 & $9.6 \pm 0.98$ & $12.30 \pm 0.26$ \\
50 & $5.3 \pm 0.27$ & $5.60 \pm 0.25$ \\
75 & $1.3 \pm 0.26$ & $2.60 \pm 0.27$ \\
100 & 0 & N/A \\
200 & 0 & N/A \\
\hline
\end{tabular}

SE: $n=4$, MMC: Multiple meristem culture

After 14 days the individual plantlets were separated and transferred to Murashige and Skoog medium supplemented with $1 \%(\mathrm{w} / \mathrm{v})$ of activated charcoal and within 14 days the hairy root started to develop.

\section{DISCUSSION}

In this experiment have shown that the increased concentration of BA for induction of rudimentary meristem and white floral meristem did not show any responses but were instead covered by thick black layer or brown in color and eventually become necrotic or death. It is thus postulated that increase of BA concentration more than $100 \mu \mathrm{M}$ induced necrosis to the explants. It has been reported ${ }^{[11]}$ that, each banana cultivar has an optimum concentration for maximum responses, beyond which the proliferation cannot be increased or even decreased.

In this experiment NAA have induced stimulating effect on compact floral meristems. The compact floral meristems exhibited maximum number of $9.6 \pm 0.98$ green multiple meristem cultures per surface. when transferred to medium supplemented with $20 \mu \mathrm{M}$ of NAA . This implies that NAA have induced active meristem. This is supported by finding of Krikorian et $a l .{ }^{[13]}$ reported that only the active meristems of the inflorescence apices will directly be induced to form multiple shoots in culture.

\section{CONCLUSION}

In this study, we successfully produced green multiple meristem culture derived from inflorescent male bud and successfully regenerated a plantlet. Further study may also be carry out by using these green competent meristems as an alternative material 
for induction of somatic embryogenesis cells suspension in future.

\section{ACKNOWLEDGEMENT}

We are grateful and thanks to University of Malaya for financial assistance.

\section{REFERENCES}

1. FAO. 2008. FAO Statistical Databases. http://www.fao.org/es/esc/en/15/190/highlight_191 .html

2. Ho, Y.W., Y.P. Tan and C. Mak, 1993. Micro propagated for commercial production of planting materials with special reference to banana. Proceedings of Seminar on the Fruit Industry in Malaysia, Sep. 7-9, Johor Bharu, .Malaysia. pp: 1519.

3. Morpurgo, R., S.V. Nto, R. Afza and F.J. Novak, 1994. Selection parameters for resistance to Fusarium oxysporum $f$. sp. cubense race 1 and race 4 on diploid banana (Musa acuminata Colla). Euphtica, 75: 121-129. DOI 10.1007/BF00024539/

4. Cronauer, S.S. and A.D. Krikorian, 1988. Plant generation via somatic embryogenesis in the seeded diploid banana Musa ornata Roxb. Plant Cell Rep., 7: 23-25. DOI: 10.1007/BF00272970/

5. Escalant, J.V. and C. Teisson, 1989 Somatic embryogenesis from immature zygotic embryos of the species. Musa acuminata and Musa balbisiana. Plant Cell Rep., 7: 665-668. DOI: 10.1007/BF00272056/

6. Ma, S.S., 1991. Somatic embryogenesis and plant regeneration from cell suspension culture of banana. Proceeding of Symposium on Tissue Culture of Horticulture Crop, Mar. 8-9, Taipei, Taiwan, pp: 181-188.
7. Escalant, J.V., C. Teisson and F. Cote, 1994. Amplifield somatic embryogenesis from male flowers of triploid banana and plantain cultivars (Musa spp). In vitro Cell Dev. Biol., 30: 181-186. DOI: $10.1007 /$ BF02823029/

8. Mahanom, J., Norzulaani Khalid and Rofina Yasmin Othman, 2003. Plant regeneration from embryogenic suspension cultures of Musa acuminate cv. Mas (AA). Plant Cell Tiss. Organ Cult., 75: 209-214. DOI : 10.1023/A:1025814922547 /

9. Grapin, A., J.L. Ortiz, T. Lescot, N. Ferriere and F.X. Cote, 2000. Recovery and regeneration of embryogenesis cultures from female flowers of False Horn Plantain (Musa AAB). Plant Cell Tiss. Organ Cult., 61: 237-244. DOI: 10.1023/A:1006423304033/

10. Stover, R.H. and N.W. Sidmmonds, 1987. Banana. In: Longman Scientific and Technical. Group Limited, London, pp : 468-477.

11. Resmi, L. and A.S. Nair, 2007. Plantlet production from the male inflorescence tips of Musa acuminata cultivars from South India. Plant Cell Tiss. Organ Cult. , 88: 333-338. DOI: 10.1007/s11240-007-9206-7.

12. Cronauer, S.S. and Krikorian, 1985. Aseptic multiplication of banana from excised floral apices. Horticulture, 20: 770-771. ISSN 0018-5345

13. Krikorian, A.D., H. Irizarry, S.S. Cronauer-Mitra and E. Rivera, 1993. Clonal fidelity and variation in plantain (Musa spp.) regenerated from vegetative stem and floral axis tips in vitro. Ann. Bot., 71: 519-535. DOI: 10.1006/anbo.1993.1068. 